\title{
Legal Politics of Simplifying Political Parties in Indonesia \\ (Case Study of $2004-2014$ Election)
}

Moch. Andry W. W. Mamonto

Universitas Muslim Indonesia

email: moch.andrymamonto@umi.ac.id

\begin{abstract}
Combination of presidential government systems and multi-party systems as a system of Indonesian state has led to a government that does not effective and stable. The formulation of the problem which is the focus of the study in this paper, namely how is the legal politics of simplification of political parties in Indonesia for the period $2004-2014$. The research method used in this study is normative. Based on the results of the study, the authors obtained answers to the existing problems, that the legal politics of simplifying political parties in Indonesia is democratic legal politics, but the legal politics of simplifying political parties in Indonesia should not only be directed at simplifying political parties in parliament, but also simplifying political parties in political parties participating in the general election.
\end{abstract}

Keywords : Legal Politics; Simplification; Political Parties.

\section{INTRODUCTION}

One of the spirits of the changes to the 1945 Constitution of the Republic of Indonesia (from now on abbreviated as the 1945 Constitution of the Republic of Indonesia) is to strengthen the building of a presidential government system. ${ }^{1}$ The spirit of the amendment to the 1945 Constitution of the Republic of Indonesia to strengthen the building of presidential government systems is one of them characterized by the formulation of Article 6A paragraph (1) and Article 22E paragraph (1) and (2), where the principal stipulates that the mechanism for filling the position of President and Vice President (hereinafter abbreviated The Vice President) is elected directly by the people. Based on these provisions, then theoretically Indonesia has adopted one of the characteristics of a presidential government system, in the language of C. F. Strong it is called the system of non-parliamentary executive government (fixed executive). ${ }^{2}$ Since the stipulation of the regulation to date, Indonesia has held three general elections (from now on abbreviated to elections) of the President and Vice-President, namely in 2004, 2009 and 2014.

${ }^{1}$ Asshiddiqie, J. (2007). Membangun Budaya Sadar Berkonstitusi untuk Mewujudkan Negara Hukum yang Demokratis. In Peringatan Dies Natalis ke XXI dan Wisuda 2007 Universitas Darul Ulum (Unisda) (29 December 2007 ed.). Lamongan: Universitas Darul Ulum (Unisda).

${ }^{2}$ Strong, C. F. (2015). Konstitusi-Konstitusi Politik Modern: Studi Perbandingan tentang Sejarah dan Bentuk. Bandung: Nusamedia, p. 355. Vide Lijphart, A. (1995). Sistem Pemerintahan Parlementer dan Presidensial (I. R., Trans.). Jakarta: PT. Raja Grafindo Persada, p. 44. 
In practice post-reformation in Indonesia has not only changed the face of the Indonesian government system, but also changed the face of the Indonesian party system. The change in the face of the Indonesian party system is marked by providing life insurance for political parties, even further political parties are positioned as organizations that have an essential function as formulated in Article 6A paragraph (2) and Article 22E paragraph (3), where political parties are participating organizations elections and organizations that have the right to nominate candidates for President and Vice President. As stated by Fransje Molenaar that, the constitution is the most special part in the regulation of political parties because it contains fundamental values and legitimizes political rules. ${ }^{3}$

The life of political parties continues to experience a metamorphosis, wherein the 2004 election period there were 24 (twenty-eight) political parties participating in the election and 16 political parties (sixteen) who won seats in the DPR, ${ }^{4}$ in the 2009 election period, there were 44 (forty-four) political parties Election participants and 9 (nine) who won seats in the DPR, ${ }^{5}$ in the 2014 election there were 12 (twelve) election political parties and 10 (ten) who won seats in the DPR. ${ }^{6}$ Starting from the description above, it appears that since 1999, 2004, 2009 to 2014 Indonesia has experienced a change in the face of the party system, both in the party system of participants in the elections and in the party system in the legislature.

From the foregoing, it is illustrated that, in connection with the changes in the provisions of the 1945 Constitution of the Republic of Indonesia concerning the regulations for the distribution of power, the mechanism for filling in the position of President and Vice President, and changes in party arrangements, has brought Indonesia under conditions of a combination of presidential and party system multi-party.

The combination of presidential government systems and multi-party systems is a difficult combination; it is also emphasized that adhering to the combination of the two systems as a state system will potentially lead to deadlock and the divided government argued by Mainwairing. ${ }^{7}$ Furthermore, Antonio Cheibub added that the magnitude of the potential deadlock would be more complicated if the president came from a small party, while forming a coalition to gain parliamentary support to develop an effective and stable government tended to be more difficult in a presidential government system. ${ }^{8}$

In the context of Indonesian state administration, the warning of the implications of

${ }^{3}$ Molenaar, F. (2012). Latin American Regulation of Political Parties: Continuing Trends and Breaks with the Past. Working Paper Series on the Legal Regulation of Political Parties(17), p. 2.

${ }^{4}$ Sulastri, E., Suparno, Yatim, S. S., \& Wijayakusuma, M. (Eds.). (2010). Modul 1: Pemilih untuk Pemula. Jakarta: Komisi Pemilihan Umum, p. 43.

5 lbid., pp. $45-46$.

${ }^{6}$ Partai Politik Pemilihan Umum Tahun 2014. (2014, 14 Agustus 2016). Retrieved from http://www.kpu.go.id/ index.php/pages/detail/2014/282

${ }^{7}$ Lijphart, A. (1995). Op. Cit., p. 19.

${ }^{8}$ Haris, S. (2014). Praktik Parlementer Demokrasi Presidensial Indonesia. Yogyakarta: CV. Andi Offset, p. 138. 
the combination of presidential systems and multi-party systems as proposed by experts, can at least be traced during the Yudhoyono-Kalla administration as the first president and vice president born of the presidential and vice-presidential election system in history Indonesian state administration. First, the president's prerogative rights are reduced in appointing and dismissing ministers. The reduction of the president's pre-procedural powers was caused by the opening of coalition taps involving several political parties in the formulation of the cabinet; even the cabinet reshuffle was not based on objective needs but the pressure of political parties. ${ }^{9}$

Secondly, the coalition building that was built to be the support of the formation of an effective government has not been able to materialize. The failure of the coalition to support the effectiveness of government is caused by the building of coalitions that are built not based on the prevailing view in managing the country, but on the attitude of pragmatism. The failure of the coalition building is increasingly complex with no discipline in the coalition by political parties. ${ }^{10}$

Based on the description above, various ideas have been created to simplify political parties; this is based on the reasoning of the arguments spoken by experts. Theoretically, to form a simple party system. So, it can be done through political life engineering through law. As stated by the Roscue Pound in Mahfud's legal politics study, that the law must be able to control and manipulate the development of society including its political life (law as a tool of social engineering). ${ }^{11}$

Thus, while the focus of the problem formulation in this study is how is the legal politics of simplifying political parties in Indonesia during the $2004-2014$ election period?

\section{METHOD}

Viewed in terms of the focus of the study, legal research conducted by the author includes the type of normative research, normative legal research is legal research conducted by selecting library materials or secondary data. In normative legal research, the process of collecting data is focused on efforts to obtain secondary data. Secondary data consists of primary legal materials, secondary legal materials, and tertiary legal materials.

${ }^{9}$ Golkar Party: 128 Members in the People's Representative Council of the Republic of Indonesia (DPR RI) and 4 Ministers in the Cabinet; United Development Party (PPP): 58 Members in the DPR and 2 Ministers in the Cabinet; Democratic Party: 55 Members in the DPR and 2 Ministers in the Cabinet; National Mandate Party (PAN): 53 Members in the DPR and 2 Ministers in the Cabinet; The National Awakening Party (PKB): 52 Members in the DPR and 2 Ministers in the Cabinet; Prosperous Justice Party (PKS): 45 Members in the DPR and 3 Ministers in the Cabinet; Crescent Star Party (PBB): 11 Members in the DPR and 1 Minister in the Cabinet; and Indonesian Justice and Unity Party (PKPI): 1 Member in the DPR and 1 Minister in the Cabinet.

${ }^{10}$ Haris, S. (2014). Op. Cit, pp. $9-11$.

${ }^{11}$ D., M. Mahfud M. (1999). Pergulatan Politik dan Hukum di Indonesia. Yogyakarta: Gama Media, p. 70. 


\section{ANALYSIS AND DISCUSSION}

Concerning state policy referred to in this study is the policy of regulating political parties, which by experts are called party law. The legal definition of the party by experts has a different view. For example Avnon, party law covers all aspects of political parties including legal status, membership, finance, organization, ideology and programs, campaigns, demonstrations and elections. ${ }^{12}$ Not much different from Avnon, Wolfgang C. Miller and Ulrich Siebeber understood party law as a law specifically designed to regulate the life of the party organizations or the whole laws that affect political parties. Specifically, the political party arrangements can be derived through the constitution, party-specific laws, election laws and campaigns, parliamentary organizations, party finances, other political activities (demonstrations), or laws that generally regulate about voluntary organizations. ${ }^{13}$

Furthermore, Kenneth Janda explained more comprehensively that what is meant by party law is the whole law that affects political parties, which include: constitution, electoral law, campaign law, party finance law, legal party access to the media, community organization law, legislative provisions, administrative decisions and court decisions. ${ }^{14}$

From the above description, it relates to the official state policy on the whole life of political parties, which in legal studies is known as the study of legal politics, with a simple understanding interpreted as the official state policy line that will be enforced nationally to achieve the country's goals. ${ }^{15}$

Theoretically, in analyzing the relationship between law and politics related to two variables, namely law (a legal product) as the dependent variable (affected variable, effect) and politics as an independent variable (variable influence, cause).${ }^{16}$ Legal politics in its study focuses on two variables which give birth to specific legal product characteristics, as argued in the Mahfud study that democratic political configurations will give birth to legal products that are responsive or autonomous, whereas conservative / orthodox or oppressive political configurations, according to Mahfud, are choices over assumptions that law is a political product will lead to the adoption of a hypothesis that certain political configurations will give birth to certain legal product characters, where democratic political configurations will give birth to responsive or autonomous legal products while authoritarian (non-democratic) political configurations will give birth to legal products with character conservative / orthodox or oppressive, can be illustrated in the following chart: ${ }^{17}$

\footnotetext{
${ }^{12}$ Katsina, A. M. (2014). Party Politics and Party Laws in New Democracies: The Case of Nigeria in the Fourth Republic, 1999 - 2011. International Journal of Humanities and Social Science, 4(2), p. 143.

${ }^{13}$ Katz, R. S., \& Crotty, W. (2014). Handbook Partai Politik. Bandung: Nusamedia, p. 719.

${ }^{14}$ Casal-Bértoa, F., Piccio, D. R., \& Rashkova, E. R. (2012). Party Law in Comparative Perspective. Working Paper Series on the Legal Regulation of Political Parties(16), p. 5.

${ }^{15}$ D., Moh. Mahfud M. (1998). Politik Hukum di Indonesia. Jakarta: LP3ES, p. 1.

${ }^{16}$ Husein, M. Wahyudin, \& Hufron, H. (2008). Hukum, Politik, \& Kepentingan. Yogyakarta: LaksBang PRESSindo, p. 1

${ }^{17}$ D., M. Mahfud M. (1999). Op. Cit., p. 6.
} 
Figure I.

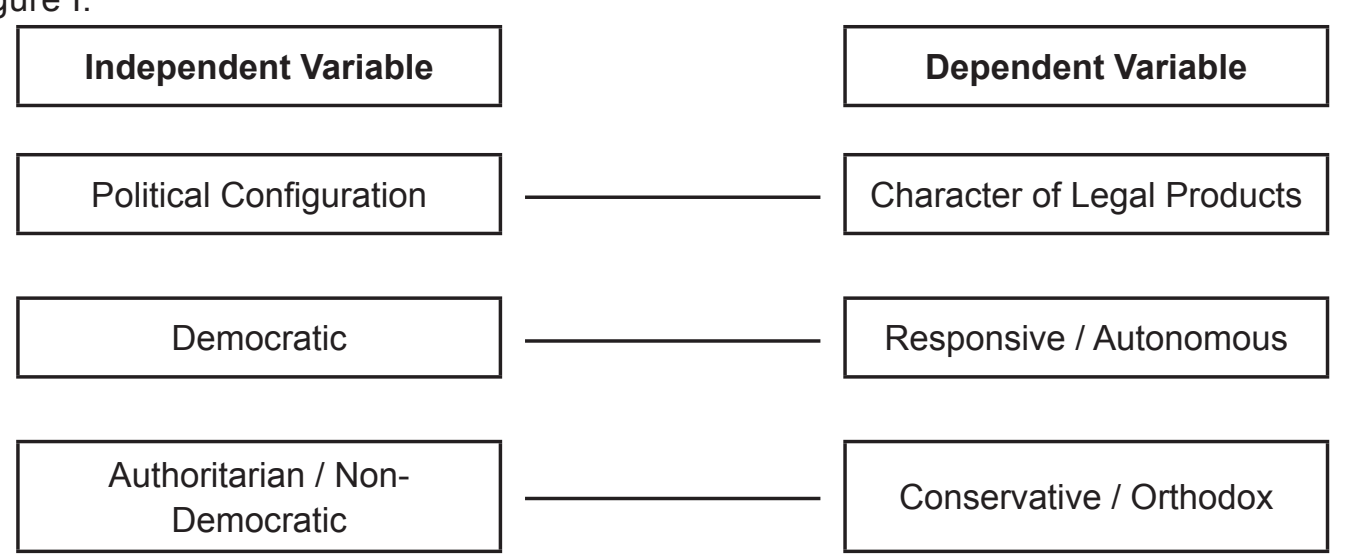

Source: Moh. Mahfud M. D., 1999.

Moh. Mahfud MD also wrote:

... it should be stated that the qualifications regarding the political configuration and character of legal products cannot be identified absolutely because in reality, no country is fully democratic or fully authoritarian, nor is there a country whose legal product character is absolutely responsive or absolute conservative. ${ }^{18}$

Based on the description above, then to understand the legal politics of simplification of political parties in Indonesia during the 2004 - 2014 general election period in this study, identification was carried out by tracing the statutory provisions that had been enacted from $2004-2014$ to simplify the political parties as follows:

\section{A. Politics of Regulatory Law Simplification of Reformed Political Parties}

Over the past 32 years, the New Order government retained its power, conditions where the country was very strong, and the state as the sole interpreter of truth. It is not wrong to describe the condition at that time by putting the government as the sole interpreter of all aspects of life, including the interpretation of the life of political parties, where the condition that everything that comes out of the mouth of the ruler is true, there is no room to refute, if anyone disputes, the catastrophe will approach them critics including among them criticism of the life of political parties, simply as it was in France with the expression of King Louis XIV “L'Etat, c'est moi", until finally the new order government ends.

The collapse of the New Order period signifies that Indonesia entered a new phase known as the Reformation, at this time began to change the state of living conditions including the life of political parties marked by the birth of Law Number 2 of 1999 concerning Political Parties to replace Law Number 3 In 1975 relating to Political Parties and Groups of Work and Law Number 3 of 1985 pertaining to Amendments to

\footnotetext{
${ }^{18}$ D., Moh. Mahfud M. (1998). Op. Cit., p. 5.
} 
Law Number 3 of 1975 concerning Political Parties and Functional Groups. ${ }^{19}$

\section{Legal Politics of Simplifying Political Parties 1999 Election Period}

Birth of a policy to form a political party law at the beginning of the Reformation era was a policy that was born to respond to the social turmoil that occurred in 1998, where there was a shift in the pendulum of social life from Authoritarian to Democratic. Policies that open space for the life of political parties has been the trigger for the growth of political parties as happened at the beginning of independence.

The power of policy that regulates the lives of political parties through is not much different from the policy power that regulates the lives of political parties in the early days of independence. The Vice President's announcement about the recommendation for the formation of political parties has also triggered the birth of fantastic numbers of political parties. Proved through Law No. 2 of 1999 were born political parties as many as forty-eight political parties which were political parties participating in the elections in 1999.

In the policy of regulating the life of political parties, it was stipulated that to form political parties must fulfill the following:

a. Conditions Requirements for Establishing Political Parties

Based on Law Number 2 year 1999, to form a political party, it must be created by at least 50 citizens of the Republic of Indonesia who are 21 years old, have Articles of Association that contain principles or characteristics and party aspirations and programs that do not conflict with Pancasila, and do not use the same name or symbol with foreign countries, the Republic of Indonesia national flag, foreign country flags, images of individuals and other party symbols. ${ }^{20}$ Furthermore, to become a legal entity, the political parties must register with the RI Justice Department using a notary deed, and include the terms of the formation of political parties as described previously. The political parties that fulfill the requirements and are declared eligible will be legalized as legal entities and announced in the State Gazette of the Republic of Indonesia. ${ }^{21}$

b. Political Party Financial Provisions

To support the life of political parties and to control political parties, political party financial policies are regulated in CHAPTER VI which include: (a) funding sources; (b) maximum amount; (d) financial statements.

\footnotetext{
${ }^{19}$ Law of the Republic of Indonesia Number 2 of 1999 (Law No. 2 of 1999) concerning Political Parties. State Gazette of the Republic of Indonesia, Number 22 of 1999. Supplement to the State Gazette of the Republic of Indonesia, Number 3809.

${ }^{20}$ Vide Article 2 Paragraph (2) of Law No. 2 of 1999.

${ }^{21}$ Vide Article 4 Paragraph (1), (2) and (3) of Law No. 2 of 1999.
} 
Political parties can obtain funding sourced from membership fees, donations and other legitimate ventures, assistance from the state budget given based on votes in general elections. Regarding the funding source, the funding sources are regulated either in the form of donations or assistance from foreign parties. ${ }^{22}$ Furthermore, it is also stipulated that political parties as non-profit organizations are prohibited from establishing business entities and owning shares in a business entity. ${ }^{23}$

In connection with the boundaries of donating funding sources, it is limited that political parties can receive donations from a maximum of Rp. 15,000,000 (fifteen million rupiahs) and contributions from other companies or entities amounting to Rp. 150,000,000 (one hundred and fifty million rupiahs) in one year. In addition to donations of money, political parties can also receive contributions in the form of goods whose value is the same as donations in the form of money. ${ }^{24}$

Thus, to control political party finances both in terms of income and expenditure, the policy regulates the obligation for political parties to report at the end of the year 15 days before, and 30 days after the general election to the Supreme Court, reports submitted to the Supreme Court contains a list of contributors. The party financial report can be audited by a public accountant appointed by the Supreme Court. ${ }^{25}$

c. Prohibition, Supervision and Dissolution of Political Parties

In Law No. 2 of 1999 stipulates that political parties are prohibited from adhering to, developing, spreading the teachings or understandings of Communism / Marxism / Leninism and other teachings that are contrary to the Pancasila. ${ }^{26}$ The institution that has the authority to supervise, freeze, dissolve, impose administrative sanctions, and revoke the right of political parties to take part in general elections for political parties proven to violate the provisions prohibited in the law is the Supreme Court.

In the 1999 general election, the policy of regulating the life of political parties was not only regulated in the laws of political parties. The policies governing the life of political parties are also regulated in Law No. 3 of 1999. ${ }^{27}$

\footnotetext{
${ }^{22}$ Vide Article 12 Paragraph (1), (2), (3) and (4) of Law No. 2 of 1999.

${ }^{23}$ Vide Article 12 Paragraph (1) and (2) of Law No. 2 of 1999.

${ }^{24}$ Vide Article 14 Paragraph (1), (2), and (3) of Law No. 2 of 1999.

${ }^{25}$ Vide Article 15 Paragraph (1) and (2) of Law No. 2 of 1999.

${ }^{26}$ Vide Article 16 Letter (a) of Law No. 2 of 1999.

${ }^{27}$ Law of the Republic of Indonesia Number 3 of 1999 (Law No. 3 of 1999) concerning General Election. State Gazette of the Republic of Indonesia, Number 23 of 1999. Supplement to the State Gazette of the Republic of Indonesia, Number 3810.
} 
In this policy it is regulated, to become an election participant political parties must fulfill the requirements, including: (a) their existence is recognized in accordance with the law on political parties; (b) has management in more than half the number of provinces in Indonesia; (c) have management of more than $1 / 2$ the number of districts / municipalities in the province; (d) submit names and images of political parties. ${ }^{28}$

\section{B. Legal Politics of Simplifying Political Parties Election Period 2004}

\section{Politics of the Law of Harmonizing the Party through Political Law}

Parties legal policy of simplifying political parties in the 2004 general elections is regulated in Law No. 31 of $2002^{29}$ Which constitutes the second political party law post-reformation replaces Law No. 2 of 1999. The matters stipulated in the policy of simplification of political parties include:

a. Terms of Establishment and Establishment of Political Parties

Political concretization of the simplification of political parties relating to the terms of establishment and formation of political parties stipulates that the conditions for establishing and establishing political party, which is established by a minimum of 50 Indonesian citizens aged 21 years with a notary deed that includes the articles of association and by-laws, and management at the national level. The provisions for the establishment and establishment of political parties refer to the formulation of Chapter II Article 2, Article 3, and Article 4.

Furthermore, the legal politics of simplifying political parties stipulates that to become a public legal entity for political parties, political party organizations must register with the Department of Justice. To become a public legal entity as described above, political parties must fulfill the requirements, namely: (a) notary deed in accordance with the 1945 Constitution and other laws and regulations, (b) having a minimum of $50 \%$ minimum management of the Province, $50 \%$ each Regency / City in the Province concerned and $25 \%$ of the number of Subdistricts in each Regency / City involved, (c) have names, (d) symbols and images that are not the same as names, (e) symbols and image signs of other political parties and have a permanent office. The legal politics of simplifying political parties are regulated in Article 2 paragraph (3).

\footnotetext{
${ }^{28}$ Vide Article 39 Paragraph (1) of Law No. 3 of 1999.

${ }^{29}$ Law of the Republic of Indonesia Number 31 of 2002 (Law No. 31 of 2002) concerning Political Parties. State Gazette of the Republic of Indonesia, Number 138 of 2002. Supplement to the State Gazette of the Republic of Indonesia, Number 1425.
} 
b. Terms of Principle and Characteristics

Apart from the management requirements and deed of establishment of the party, legal politics simplifying political parties also regulates the provisions regarding the basic terms and characteristics of the party, that each political party must not adhere to the principles and characteristics that are contrary to Pancasila and the 1945 Constitution. Political parties can include specific characteristics by their wishes and ideas that do not conflict with the Pancasila, the 1945 Constitution of the Republic of Indonesia, and the Act. The arrangement of principles and characteristics of political parties is formulated in Article 5 paragraph (1) and (2).

c. Political Party Financial Arrangements

Legal politics of simplifying political parties through political party financial arrangements are regulated through the provision of financial resources that can be accepted by political parties which include: (a) membership dues with a maximum limit of $200,000,000$ (b) lawful good contributions in the form of money, goods, facilities, equipment and equipment with a maximum limit of $800,000,000$ and (c) assistance from the state budget that gives proportionally to political parties that get seats in the institutions of the people's representatives. Regarding legal politics, the simplification of political parties regarding the provisions of financial arrangements for political parties is regulated in Article 17 paragraph (1), (2), and (3) and Article 18 paragraph (1) and (2).

d. Prohibitions and Sanctions

In the legal politics of simplifying political parties Law Number 31 of 2002, in addition to regulating the provisions concerning rights granted to political parties. The law also regulates provisions concerning restrictions in the form of prohibitions or sanctions.

About prohibited provisions it is categorized into two, namely: administrative prohibitions and prohibitions on the activities of political parties. The prohibition concerning administration, in the form of prohibition of names, symbols and images that resemble: (a) the flag or symbol of the Republic of Indonesia, (b) the symbol of a state or government institution, (c) name, flag or symbol of another country and name, flag or symbol of an international institution / agency, (d) someone's name and picture and, (e) having similarities with other political parties whereas the prohibition relating to the activities of political parties includes: events that are contrary to the 1945 Constitution and laws, endangering the Unitary Republic of Indonesia, and contrary to the policies of the state government in maintaining a friendship with other countries in order to maintain world order. 
Concerning provisions concerning the prohibition of the establishment of business entities and share ownership, and the prohibition of receiving and giving contributions from/to the following details: (a) foreign parties; (b) any party without including a clear identity; (c) the person / institution exceeds the specified limit; (d) BUMN, BUMD, BUMDes, cooperatives, foundations, NGOs, community organizations and humanitarian organizations. It is further regulated by the prohibition of Political Parties to adhere to, develop and spread the teachings or understandings of Communism / Marxism-Leninism.

Based on these provisions, there are 24 (twenty-four) political parties that are declared legitimate as legal entities and passed the administration.

\section{Legals Politics of Simplifying Political Parties through Election Laws}

A policy of simplifying political parties through electoral law in the 2004 general election is regulated in Law No. 12 of 2003 concerning General Elections of Members of the DPR, DPD and DPRD. The matters stipulated in the political party's simplification policy in the law include:

a. Requirements to Become Election Participants

Policy of providing political parties regarding the requirements to become political parties participating in elections specifies that in order to become an eligible participant, political parties must comply with: (a) have a legislative board of at least $2 / 3$ of the total number of provinces; (b) have a complete management of at least $2 / 3$ of the total districts / cities in the province concerned; (c) having a membership of at least $1 / 1000$ of the total population in each management of a political party, must have a permanent office and submit the names and images of political parties to the KPU. The policy of simplifying political parties related to the requirements to become an election participant is regulated in Article 17.

b. Requirements for Following the Election of the Next Period and Requirements for Obtaining Chairs

Next, it is determined that to take part in the next election period, political parties must fulfill the provisions for the seats, namely: (a) at least $3 \%$ of DPR seats; (b) Obtain at least $4 \%$ of the total seats in the Provincial DPRD which are spread at least in $1 / 2$ (half) of the total provinces in Indonesia; or (c) Obtain at least $4 \%$ of the number of Regency / City DPRD seats spread in $1 / 2$ (half) of the number of regencies / cities in Indonesia. The policy of simplifying political parties through the requirements for obtaining vote thresholds is regulated in Article 9. With the enactment of the provisions of Article 9 paragraph (1), political parties not fulfilling these provisions have no right to place candidates to sit or obtain seats 
in the DPR, Provincial DPRD, and Regency / City DPRD. The other implications of the enactment of this provision are that each political party participating in the election cannot automatically become an election participant in the following period. Political parties participating in the 2004 elections can become election participants in the 2009 period, only if they join a political party participating in an election that meets the requirements of the election participants; join a political party that does not fulfill the needs of the election participants and then uses the name and sign of one of the political parties joining so as to meet the minimum number of seats; or join a political party that does not fulfill the requirements of election participants by forming a new political party with new names and images so as to meet the minimum number of seats. Provisions to merge parties for electoral party parties that do not fulfill the provisions of Article 9 paragraph (1) are contained in paragraph (2).

\section{Legal Politics of Simplifying Political Parties 2009 Election Period}

By referring to the results of the 2004 general election, policymakers in the 2009 elections made changes to the policy direction to simplify political parties. Furthermore, changes in the direction of policy simplification of political parties due to the simplification of political parties through law 31 of 2002 are considered not optimal in accommodating the development of society. So it is deemed necessary to determine the new direction of legal politics simplifying political parties.

\section{The Politics of Law for the Elimination of Political Parties through Political Party Laws}

Policy of simplifying political parties through the laws of political parties in the 2004 general elections is regulated in Law Number 2 of 2008 concerning Political Parties ${ }^{30}$. The matters stipulated in the political party's simplification policy in the law include:

a. Terms of Establishment of Political Parties

In the change in the legal political direction of the simplification of the political party it was determined that, to establish a political party must meet the requirements including: establishment by a minimum of 50 citizens the 21-yearold Indonesian state (WNI) with a notary who included $30 \%$ representation of women and included $A D$ and $A R T$ and management at the central level. $A D$ party contains: principles and characteristics of the party, vision and mission, name, symbol, and signatures, goals and functions of parties, organizations,

\footnotetext{
${ }^{30}$ Law of the Republic of Indonesia Number 2 of 2008 (Law No. 2 of 2008) concerning Political Parties. State Gazette of the Republic of Indonesia, Number 2 of 2008. Supplement to the State Gazette of the Republic of Indonesia, Number 4801.
} 
place of domination and decision making, party rules and decisions, political education and political party finance. ${ }^{31}$

b. Requirements to Become a Public Legal Entity

Furthermore, the policy of simplifying political parties regulates that to become a public legal entity, the organization of a political party must fulfill the following requirements: (a) ownership of the deed of establishment of the party; (b) names and symbols / images that are not the same as other parties; (c) have a permanent office and have management in at least $60 \%$ of the total provinces, $50 \%$ in the district / city in question and have an account in the name of the party. ${ }^{32}$

c. Terms and Regulations on Principles or Ideology and Characteristics of the Party

In the policy of regulating the simplification of political parties not only carried out through the requirement to become a public legal entity, the simplification efforts are also carried out through the provisions of fundamental/ ideological requirements and party characteristics that political parties can include certain characteristics and reflects the will and ideals of political parties that do not conflict with Pancasila and the 1945 Constitution. ${ }^{33}$

d. Financial Arrangements of Political Parties

Regarding the policy of simplifying political parties through the regulation of political party, finances are carried out through restrictions on financial resources which include: (a) membership fees, (b) other legal sources, and (c) financial assistance from the APBN / APBD that is given proportionally by the vote acquisition. ${ }^{34}$

Furthermore, the policy of regulating the simplification of political parties in regulating financial parties related to their implementation is given authority to political parties to control in AD and ART. However, what needs to be addressed is that restrictions pertaining to individual contributions not from members of political parties are limited to one billion rupiahs per year, while contributions from companies and Business Entities are a maximum of four billion rupiahs per year.

e. Prohibitions and Sanctions

The new direction of the policy of simplifying political parties stipulated in the political party law also regulates the provisions of prohibitions and sanctions.

\footnotetext{
${ }^{31}$ Vide Article 2 Paragraph (1), (2), (3) and (4) of Law No. 2 of 2008.

${ }^{32}$ Vide Article 3 Paragraph (1) and (2) of Law No. 2 of 2008.

${ }^{33}$ Vide Article 9 Paragraph (1) and (2) of Law No. 2 of 2008.

${ }^{34}$ Vide Article 34 of Law No. 2 of 2008.
} 
Requirements for ban include the name and symbol of the party, party activities, funding sources and the establishment of business entities, the teachings of communism. ${ }^{35}$ The details are as follows:

1) Names and Symbols of political party parties are prohibited from using the name and symbol of the same party as the ${ }^{36}$

a) flag or symbol of the Republic of Indonesia;

b) symbol of a state institution or Government symbol;

c) Name, flag, the emblem of another country or international institution/ body

d) name, flag, a symbol of the organization of a separatist movement, or a prohibited organization;

e) someone's name or picture; or

f) that has the same equality or the whole with the name, symbol or picture of another Political Party.

2) Political Party Activities

A policy of simplifying political parties regulated through the prohibition of the activities of political parties stipulates that political parties are prohibited from carrying out activities that contradict the 1945 Constitution of the Republic of Indonesia and laws or conduct activities that endanger the integrity and safety of the unitary State Republic of Indonesia. ${ }^{37}$

In order to regulate the activities of political party funding sources, in the policy of regulating the simplification of political parties the provisions are in the form of prohibitions for political parties to accept and contribute to foreign parties, from parties whose identity is unclear, take contributions exceeding the prescribed limits and receive donations from BUMN / BUMD, uses fractions as a source of funding. ${ }^{38}$ It is further stipulated that political parties are prohibited from establishing business entities and owning shares of a business entity.

Regarding political party activities related to the life and development of political parties, the policy of simplifying political parties regulates the prohibition to adhere to and develop and spread the teachings or understandings of communism / Marxism-Leninism.

\footnotetext{
${ }^{35}$ Vide CHAPTER XVI of Law No. 2 of 2008.

${ }^{36}$ Vide Article 40 Paragraph (1) of Law No. 2 of 2008.

${ }^{37}$ Vide Article 40 Paragraph (2) of Law No. 2 of 2008.

${ }^{38}$ Vide Article 40 Paragraph (3) of Law No. 2 of 2008.
} 
To provide the workforce for the prohibitions regulated in the policy of simplifying the political parties, a policy for imposing sanctions on violating political parties was born. The policy provisions related to sanctions for violating political parties can be in the form of rejecting the registration of political party organizations into legal entities by the Department. Furthermore, for political parties that violate the provisions of Article 13 letter I, will be subject to sanctions for termination of the provisions of the State / Regional Revenue and Expenditure Budget until the government receives the report in the relevant fiscal year. Whereas for political parties that violate the provisions of Article 40 can be subject to sanctions in the form of freezing and dissolution.

\section{Simplification of Political Parties through Election Law}

About the simplification policy of political parties through the electoral law regulated in Law Number 10 of 2008 concerning General Elections of Members of the House of Representatives, Regional Representatives ${ }^{39}$ set that :

a. Requirements to Become Election Participants

The new direction of legal political change in the simplification of political parties is regulated changing conditions to become political parties participating in elections, that to become political parties participating in elections, political parties must meet the requirements : (a) legal status in accordance with the Law on Political Parties; (b) has management in $2 / 3$ of the number of provinces; (c) has management $2 / 3$ of the number of districts / cities of province concerned; (d) include at least $30 \%$ (thirty percent) women's representation in the management of central political parties; (e) Has a membership at least 1000 thousand people or 1/1000 (one thousandth) of the total population in each of the political parties management as referred to in letter $b$ and letter $c$ as evidenced by the ownership of a member card; (f) Having a permanent office for control as referred to in letter b and letter $f$; $(g)$ Submit names and images of political parties to the KPU. ${ }^{40}$

b. Requirements to get a seat in the DPR In the 2009 elections there was a change in the political direction of the policy of simplifying political parties, where to the participate in the determination of seats in the DPR, political parties achieve the acquisition of a sound threshold of at least $2,5 \%$ of the number of legitimate nations vote. ${ }^{41}$

\footnotetext{
${ }^{39}$ Law of the Republic of Indonesia Number 10 of 2008 (Law No. 10 of 2008) concerning General Elections of Members of People's Representative Council of the Republic of Indonesia, Regional Representative Council, and Regional People's Representatives Council. State Gazette of the Republic of Indonesia, Number 51 of 2008. Supplement to the State Gazette of the Republic of Indonesia, Number 4836.

${ }^{40}$ Vide Article 8 Paragraph (1) of Law No. 10 of 2008.

${ }^{41}$ Vide Article 202 Paragraph (1) of Law No. 10 of 2008.
} 
These provisions show the spirit of simplification political parties, as evidenced by the enactment of the provisions as many as thirty-eight political parties participating in the election can converge into sixteen political parties. However, the number of political parties cannot be categorized as a simple political party system as the simple political party concept referred to in this study.

\section{Legal Politics for Simplifying Political Parties in the 2014 Election Period}

\section{Legal Politics of Simplifying Political Parties through the Law on Political Parties}

Referring to the elections results in 2009, policymakers ware deemed necessary to carry out changes related to the laws of political parties and electoral laws as a new direction for the legal politics of simplifying political parties. We can trace the new direction of legal politics in the new simplification of political parties in the formulation of Law Number 2 Year 2011 concerning Amendments to Law Number 2 Year 2008 concerning Political Parties. ${ }^{42}$

The new direction of the policy of regulating the simplification of political parties is a policy that considers that law 31 of 2002 has not been optimal in accommodating the development society. So it is deemed necessary to determine the new direction of the policy of simplifying political parties.

a. Terms of Establishment of Political Parties

The changes in the direction of policy simplification of political parties are regulated by several changes in terms of the establishment of political parties, that to form a political party is established by at least 30 Indonesian citizens aged 21 years in each province, registered by at least 50 founders representing all founders party with a notary includes $30 \%$ representation of woman. Notary a deeds supplemented by AD and ART and management at the national level. ${ }^{43}$

b. Requirements to become a Public Legal Entity

Furthermore, based on the provisions of Article 3 paragraph (1), that to obtain status as a legal entity, political party organizations must register with the Ministry Law and Human Rights. To become a legal entity, political party organizations must meet the following requirements : (a) Notary deed of establishment of Political Parties; (b) name, symbol, or sign that does not have quality in the main or the whole with the name, symbol, or sign that has been legally used by other political parties in accordance with the laws and regulations; (c) Management in each province and at least $75 \%$ (seventy five percent) of the number of the

\footnotetext{
${ }^{42}$ Law of the Republic of Indonesia Number 2 of 2011 (Law No. 2 of 2011) concerning Amendment to Law No. 2 of 2008 concerning Political Parties. State Gazette of the Republic of Indonesia, Number 8 of 2011. Supplement to the State Gazette of the Republic of Indonesia, Number 5189.

${ }^{43}$ Vide Article 2 Paragraph (1), (2) and (3) of Law No. 2 of 2011.
} 
district, / cities province concerned and at least $50 \%$ (fifty percent) of the total number of sub-districts and related districts / cities; (d) Permanent offices at the central, provincial and district / city levels until the final stage of general election; (e) accounts in the name Political Parties. ${ }^{44}$

c. Funding Terms

About the legal politics of simplifying political parties through political party financial arrangements, it is regulated that the financial resources of political parties cover : (a) Membership fees; (b) Legal donations and (c) Financial assistance from the State Budget Income and Expenditures / Regional Budget. As an effort to control the sources of political party funding as referred to in the previous description. So, in the policy of regulating the simplification of political parties regulated by the provision of financial party political resources, the supervisions policy is carried out through the obligation to submit accountability reports on revenues and expenditures originating from the State Audit Agency's Regional Budget and Regional Expenditures Budget assistance periodically. Once a year to be audited no later than 1 (one) month after the end of the fiscal year. ${ }^{45}$

d. Prohibitions and Sanctions

The policy of regulating the simplification of political parties through the prohibition provisions on political parties includes the prohibition of violations of Article, Article 3, Article 9 paragraph (1), and Article 40 paragraph (1). Thus, if the political party violates the prohibition as stipulated in the description of the above article, the political party will be subject to sanctions, in the policy of regulating the simplification of political parties through sanctions can be imposed through administrative sanctions in the form of refusing the registration of political party organizations into the party's legal entity.

Whereas political parties that violate the prohibition as referred to in Article 13 letter $\mathrm{i}$, political parties will be subject to administrative sanctions in the form of preventing assistance from the State Budget for Expenditures and Expenditures / Expenditures and Regional Assistance until the report in the related fiscal year.

\section{Legal Politics for Simplifying Political Parties through Election Laws}

a. Requirements to become Election Participants

For political parties wishing to participate as electoral political parties in the holding of elections for the 2014-2019 period, they must meet the requirements 
that include:

1) Legal status in accordance with the Law on political parties;

2) Have stewardship throughout the province;

3) Has management in $75 \%$ (seventy-five per cent) of the number of districts/ cities in the province concerned;

4) Has management in $50 \%$ (fifty hundred per cent) of the number in the relevant regency/city;

5) Include at least $30 \%$ (thirty per cent) of representation of women in the management of central level political parties;

6) Has a membership of at least 1.000 (one thousand) or 1/1000 (one thousand) of the population in the management of a political party as referred to in letter $c$ as evidenced by ownership of a membership card;

7) Have a permanent office for management at the central, provincial and district/city levels until the final stages of the election ;

8) Submit names, symbols and images of political parties to the KPU; and

9) Submit the election campaign fund account number on behalf of the political party to the KPU.

The above provisions do not apply to political parties that have met the vote acquisition threshold in the previous election. Article b paragraph (1) and (2).

b. Requirements to get a seat in the DPR

In Law Number 8 of 2012 the direction of legal political pendulum simplification of political parties regulated through the implementation of parliamentary thresholds has been a shift. Where the parliament threshold of $2,5 \%$ applied in the 2009 election shifted to $3,5 \%$. The provision emphasizes that to enter into the distribution of seats, political parties must meet the vote acquisition threshold requirements of at least $3,5 \%$ (three point five per cent) of the national legitimate votes. ${ }^{46}$

With the enactment of the parliamentary vote threshold, which is $3,5 \%$, it can be simplifying political parties from twelve political parties to ten political parties that have rights in the distribution of seats in the DPR. However, the prevision shows that it has not been able to direct the formation of a simple party system referred to in this study.

${ }^{46}$ Vide Article 208 of Law of the Republic of Indonesia Number 8 of 2012 (Law No. 8 of 2012) concerning General Elections of Members of People's Representative Council of the Republic of Indonesia, Regional Representative Council, and Regional People's Representatives Council. State Gazette of the Republic of Indonesia, Number 117 of 2012. Supplement to the State Gazette of the Republic of Indonesia, Number 5316. 


\section{CONCLUSION}

The legal politics of simplifying political parties in Indonesia during the 2004 2014 general elections were carried out through the Political Party Act and the General Election Law, wherein each election period a change in legal politics was carried out. The legal-political character of simplification of political parties during the $2004-2014$ general election embraced democratic legal politics. However, overall legal politics of simplifying political parties in Indonesia during the 2004 - 2014 elections was only oriented to the simplification of political parties in Parliament, not oriented to the simplification of political parties as Election Participants.

\section{ACKNOWLEDGEMENT}

Alhamdulillahi rabbil 'alamin, thank you very much to LP2S Universitas Muslim Indonesia, which specifically provides an opportunity for author to take part in the beginner's research scheme and in general the author also express their deepest gratitude to the Universitas Muslim Indonesia who have funded this research so that it can be completed on time and can become one of the sources of reference for legal writing, which specifically addresses the issue of political parties in Indonesia. there are no more appropriate words for the author to say besides thank you.

\section{REFERENCE}

Asshiddiqie, J. (2007). Membangun Budaya Sadar Berkonstitusi untuk Mewujudkan Negara Hukum yang Demokratis. In Peringatan Dies Natalis ke XXI dan Wisuda 2007 Universitas Darul Ulum (Unisda) (29 December 2007 ed.). Lamongan: Universitas Darul Ulum (Unisda).

Casal-Bértoa, F., Piccio, D. R., \& Rashkova, E. R. (2012). Party Law in Comparative Perspective. Working Paper Series on the Legal Regulation of Political Parties(16), $1-27$.

D., Moh. Mahfud M. (1998). Politik Hukum di Indonesia. Jakarta: LP3ES.

D., Moh. Mahfud M. (1999). Pergulatan Politik dan Hukum di Indonesia. Yogyakarta: Gama Media.

Haris, S. (2014). Praktik Parlementer Demokrasi Presidensial Indonesia. Yogyakarta: CV. Andi Offset.

Husein, M. W., \& Hufron, H. (2008). Hukum, Politik, \& Kepentingan. Yogyakarta: LaksBang PRESSindo. 
Katsina, A. M. (2014). Party Politics and Party Laws in New Democracies: The Case of Nigeria in the Fourth Republic, 1999 - 2011. International Journal of Humanities and Social Science, 4(2), $142-152$.

Katz, R. S., \& Crotty, W. (2014). Handbook Partai Politik. Bandung: Nusamedia.

Law of the Republic of Indonesia Number 2 of 1999 (Law No. 2 of 1999) concerning Political Parties. State Gazette of the Republic of Indonesia, Number 22 of 1999. Supplement to the State Gazette of the Republic of Indonesia, Number 3809.

Law of the Republic of Indonesia Number 3 of 1999 (Law No. 3 of 1999) concerning General Election. State Gazette of the Republic of Indonesia, Number 23 of 1999. Supplement to the State Gazette of the Republic of Indonesia, Number 3810.

Law of the Republic of Indonesia Number 31 of 2002 (Law No. 31 of 2002) concerning Political Parties. State Gazette of the Republic of Indonesia, Number 138 of 2002. Supplement to the State Gazette of the Republic of Indonesia, Number 1425.

Law of the Republic of Indonesia Number 12 of 2003 (Law No. 12 of 2003) concerning General Elections of Members of People's Representative Council of the Republic of Indonesia, Regional Representative Council, and Regional People's Representatives Council. State Gazette of the Republic of Indonesia, Number 37 of 2003. Supplement to the State Gazette of the Republic of Indonesia, Number 4277.

Law of the Republic of Indonesia Number 2 of 2008 (Law No. 2 of 2008) concerning Political Parties. State Gazette of the Republic of Indonesia, Number 2 of 2008. Supplement to the State Gazette of the Republic of Indonesia, Number 4801.

Law of the Republic of Indonesia Number 10 of 2008 (Law No. 10 of 2008) concerning General Elections of Members of People's Representative Council of the Republic of Indonesia, Regional Representative Council, and Regional People's Representatives Council. State Gazette of the Republic of Indonesia, Number 51 of 2008. Supplement to the State Gazette of the Republic of Indonesia, Number 4836.

Law of the Republic of Indonesia Number 2 of 2011 (Law No. 2 of 2011) concerning Amendment to Law No. 2 of 2008 concerning Political Parties. State Gazette of the Republic of Indonesia, Number 8 of 2011. Supplement to the State Gazette of the Republic of Indonesia, Number 5189.

Law of the Republic of Indonesia Number 8 of 2012 (Law No. 8 of 2012) concerning General Elections of Members of People's Representative Council of the Republic of Indonesia, Regional Representative Council, and Regional People's Representatives Council. State Gazette of the Republic of Indonesia, Number 117 of 2012. Supplement to the State Gazette of the Republic of Indonesia, Number 5316. 
Lijphart, A. (1995). Sistem Pemerintahan Parlementer dan Presidensial (Ibrahim R., Trans.). Jakarta: PT. Raja Grafindo Persada.

Molenaar, F. (2012). Latin American Regulation of Political Parties: Continuing Trends and Breaks with the Past. Working Paper Series on the Legal Regulation of Political Parties(17), 1 - 38.

Partai Politik Pemilihan Umum Tahun 2014. (2014, 14 Agustus 2016). Retrieved from http://www.kpu.go.id/index.php/pages/detail/2014/282.

Strong, C. F. (2015). Konstitusi-Konstitusi Politik Modern: Studi Perbandingan tentang Sejarah dan Bentuk. Bandung: Nusamedia.

Sulastri, E., Suparno, Yatim, S. S., \& Wijayakusuma, M. (Eds.). (2010). Modul 1: Pemilih untuk Pemula. Jakarta: Komisi Pemilihan Umum. 